ABDIMAS: Jurnal Pengabdian Masyarakat Universitas Merdeka Malang
Vol.7(1) February 2022, 166-177
i-ISSN: 2721-138X e-ISSN: 2548-7159
ittp://jurnal.unmer.ac.id/index.php/jpkm

\title{
Assistance in optimizing production and sales for MSME Skippy Cookie "AYU" in Sukodadi Village, Palembang
}

\section{Pendampingan optimalisasi produksi dan penjualan UMKM Kue Skippy "AYU" di Kelurahan Sukodadi Palembang}

\author{
Indra Griha Tofik Isa', Riana Mayasari² \\ ${ }^{1}$ Departemen Manajemen Informatika, ${ }^{2}$ Departemen Akuntansi, Politeknik Negeri Sriwijaya \\ Jl. Srijaya Negara, Bukit Besar, Palembang, Sumatera Selatan, 30139, Indonesiaa
}

\begin{abstract}
ARTICLE INFO:
Received: 2021-06-21

Revised: 2021-09-20

Accepted: 2021-12-06

Keywords:

Community partnership program, Production and sales optimalization, Skippy cookie, MSME, Assistance

ABSTRACT

UMKM becomes the driving force of the community's economy and becomes a contributor to the income of a region. Palembang is an area that has an even distribution of UMKM in each sub-district, one of them is UMKM Kue Skippy "AYU" which is located in Sukodadi. UMKM Skippy Cookie "AYU" was formed in 1992 and produced peanut cookies as a home industry. Skippy Cookie "AYU" has a distinctive taste that is different from similar skippy cookies and can be a potential product for the Sukodadi area. UMKM skippy cookie "AYU" is a pillar of economic activity for the surrounding community. The problems that occur are no legality of the product, the lack of variety of skippy cookie produced, and no good financial management and factory management. So that this activity aims to increase the income and productivity of UMKM partners through the stages of methods assistance for P-IRT Legalization, assistance for skippy cookie product innovation, marketing training, and factory management assistance, and (4) Evaluation. The result of this activity is an increase in partners' income and productivity from $65 \%$ to $80 \%$.

(C) 2022 Abdimas: Jurnal Pengabdian Masyarakat Universitas Merdeka Malang This is an open access article distributed under the CC BY-SA 4.0 license (https://creativecommons.org/licenses/by-sa/4.0/)

How to cite: Isa, I. G. T., Lelo, L., \& Mayasari, R. (2021). Assistance in optimizing production and sales for MSME Skippy Cookie "AYU" in Sukodadi Village, Palembang Abdimas: Jurnal Pengabdian Masyarakat Universitas Merdeka Malang, 7(1), 166-177. https://doi.org/10.26905/abdimas.v7i1.5956
\end{abstract}

\section{PENDAHULUAN}

Palembang merupakan Kota Metropolitan yang struktur perekonomiannya ditunjang hampir sebagian besar oleh sektor industri non pertanian (Badan Pusat Statistik Kota Palembang, 2020). Salah satu aspek yang menunjang dalam perputaran roda perekonomian tersebut adalah industri makanan dan minuman (Suparjo \& Hariastuti, 2017). Hingga tahun 2019 industri makanan dan minuman termasuk didalamnya pengolahan industri makanan besar, menengah dan UMKM tercatat menempati urutan pertama dalam menghasilkan nilai tambah sektor industri non-migas, yakni sebesar 15.353.704,9 juta rupiah (Badan Pusat Statistik Kota Palembang, 2019). Dari pelaku industri makanan tersebut, UMKM 
memiliki peranan penting dalam pemberdayaan masyarakat karena sifatnya langsung dari masyarakat, oleh masyarakat dan untuk masyarakat (Isa et al., 2019). Pemberdayaan UMKM terus menerus dilakukan, baik oleh swadaya masyarakat, pemerintah maupun dunia akademik melalui pemanfaatan teknologi mesin otomatis yang memudahkan UMKM dalam meningkatkan standar mutu produk pangan (Nursalim et al., 2021) ataupun melalui pendampingan komersialisasi produk berdaya saing dan berbasis Teknologi Informasi (Harsawardana et al., 2020)

Kue kacang atau yang lebih dikenal dengan kue skippy merupakan salah satu produk kuliner rumahan yang rata-rata diproduksi oleh Industri Rumahan maupun UMKM. Kue skippy memiliki tekstur rasa yang gurih dan renyah dengan komposisi utama dari kacang, mentega, gula dan tepung terigu. Kue skippy umumnya menjadi makanan ringan yang dapat diterima oleh seluruh lapisan masyarakat, termasuk di Palembang yang mana merupakan Kota Kuliner (MC Kota Palembang, 2019).
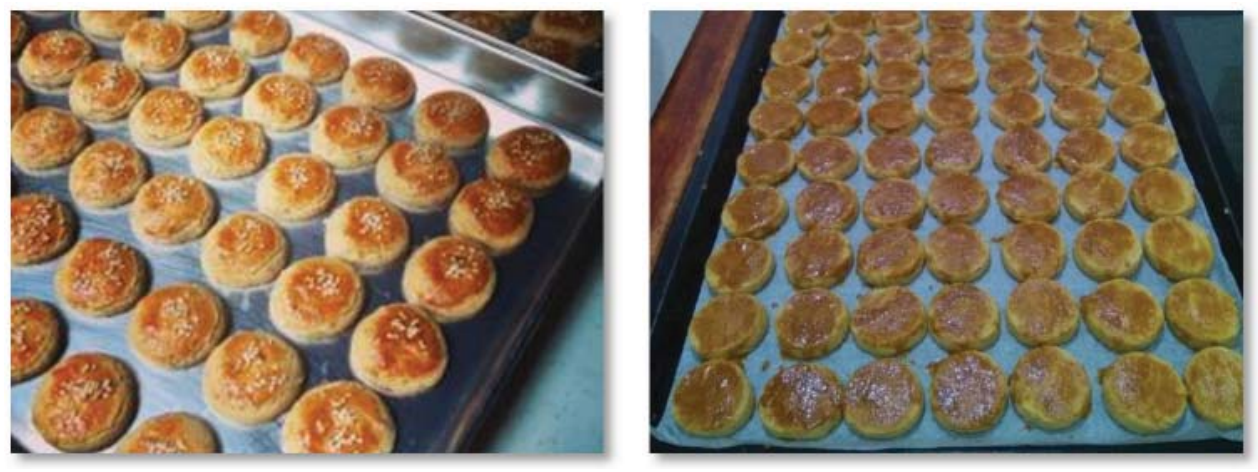

Gambar 1. Kue kacang atau kue skippy

Kelompok UMKM Skippy "AYU" adalah salah satu Kelompok UMKM yang memproduksi kue skippy sejak tahun 1992 berlokasi di Kelurahan Sukodadi, Palembang. Kue skippy yang diproduksi oleh Kelompok UMKM Skippy "AYU" ini memiliki kekhasan rasa yang berbeda dengan kue skippy lainnya, karena terbuat dari kacang pilihan yang dijemur hingga kering dan menggunakan gula tebu asli pada bahan campuran adonannya serta tanpa tambahan bahan pengawet ataupun zat kimia berbahaya. Berkat rasanya yang khas tersebut, Kue Skippy "AYU" sangat laris di pasaran dan merambah ke beberapa kabupaten diluar Kota Palembang, diantaranya Kabupaten Banyuasin, Kabupaten Musi Banyuasin, Sekayu, Sungai Lilin, dan beberapa daerah di sekitar perbatasan Sumatera Selatan dan Jambi. Bila dihitung ratarata mingguan, kelompok UMKM Skippy "AYU" dapat memproduksi sekitar 1800 pack kue Skippy untuk didistribusikan ke konsumen. Sehingga dalam memproduksi kue tersebut kelompok UMKM Skippy "AYU" mengoperasikan 3 pabrik dengan 30 anggota aktif yang berasal dari masyarakat sekitar Kelurahan Sukodadi yang didominasi oleh pekerja wanita usia antara 35 - 48 tahun. Rata-rata anggota kelompok usaha atau pekerja wanita tersebut adalah ibu rumah tangga dengan suami yang tidak bekerja ataupun sudah tidak memiliki pasangan (status janda). Sehingga mereka sangat menggantungkan nasibnya pada UMKM Kue Skippy. Dari segi pemasaran dilakukan secara konvensional, yakni dengan pelanggan mendatangi langsung ke pabrik ataupun "pengampas" mendistribusikan ke beberapa dusun yang ada di sekitar daerah Pangkalan Balai, Sekayu, Sungai Lilin dan beberapa daerah pinggiran di perbatasan Palembang dan Jambi.

Namun dalam 5 tahun terakhir, terutama pada pertengahan tahun 2016 hingga sekarang terjadi penurunan penjualan yang signifikan dimana hanya memproduksi 300 pack kue skippy di setiap pekan. Hal ini berdasarkan diskusi dengan ketua kelompok UMKM dikarenakan kejenuhan pasar dan ada 
ABDIMAS: Jurnal Pengabdian Masyarakat Universitas Merdeka Malang Volume 7, No 1, February 2022: 166-177

produk sejenis dari daerah lain yang menjadi kompetitor Kue Skippy "AYU". Sehingga pada saat ini kelompok UMKM Kue Skippy hanya mampu mengoperasikan 1 pabrik saja untuk memproduksi Kue Skippy "AYU".
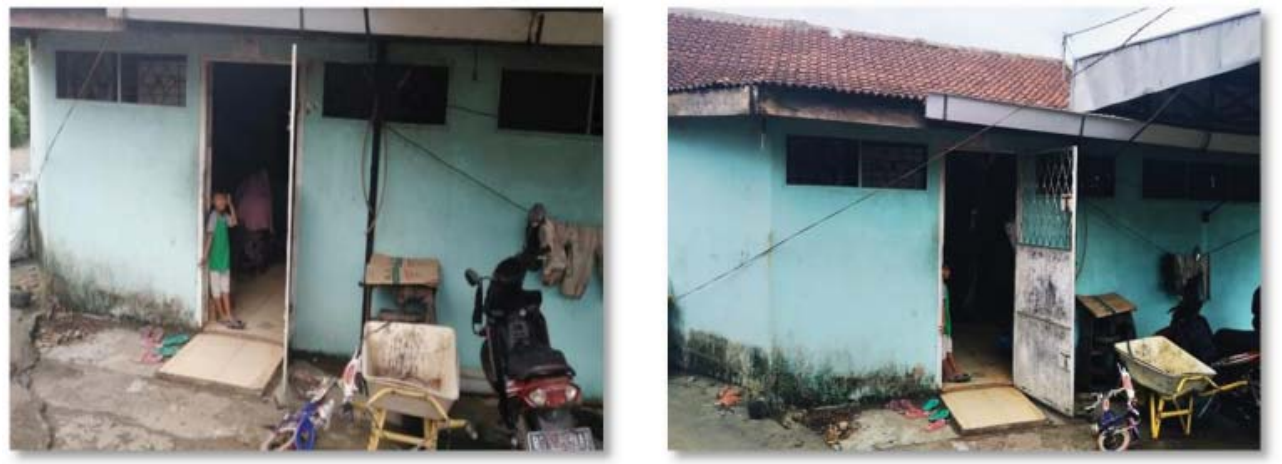

Gambar 2. Lokasi Pabrik UMKM Kue Skippy "AYU"

Secara ringkas, uraian kondisi mitra pada saat ini berdasarkan wawancara dengan mitra, terdapat dalam tabel berikut:

Tabel 1. Uraian Kondisi Mitra

\begin{tabular}{ll}
\hline \multicolumn{1}{c}{ Uraian } & \multicolumn{1}{c}{ Keterangan Mitra } \\
\hline Hasil Produk & Kue Skippy \\
Karakteristik Rasa & Renyah, gurih dan rasa manis proporsional \\
Laba bersih & Hanya mencukupi operasional, tidak ada laba ditahan untuk pengembangan kelompok \\
& UMKM \\
Kapasitas Produksi & 300 pack kue Skippy / minggu \\
Pemasaran & Secara konvensional, dengan pendistribusian oleh "Pengampas" dan menunggu pembeli \\
& datang langsung ke pabrik untuk membeli \\
Pengemasan & Plastik bening transparan \\
Jumlah anggota aktif & Tahun 2020 mempekerjakan 10 anggota aktif, dari semula berjumlah 30 anggota aktif \\
Jumlah pabrik beroperasi & Tahun 2020 beroperasi 1 pabrik dari 3 pabrik yang beroperasi \\
Jumlah hari produksi & Tahun 2020 hanya 1 - 3 hari per minggu, dari semula 6 - 7 hari per minggu \\
Daerah Pemasaran & Sekayu, Sungai Lilin, dan daerah sekitar pabrik \\
Pengelolaan Keuangan & Hanya mengukur pendapatan secara kira-kira \\
Pengelolaan Manajemen & Belum menerapkan manajemen bahan baku, pengolahan produksi dan inventori stok \\
Produksi & barang \\
\hline
\end{tabular}

Berdasarkan justifikasi pihak dan pengusul, maka permasalahan prioritas yang akan diangkat di PKM ini adalah sebagai berikut: (1) Tidak ada legalitas produk. Kue Skippy "AYU" yang beredar saat ini belum memiliki legalitas P-IRT dari mulai awal produksi pada tahun 1992 hingga sekarang. Hal tersebut mengakibatkan menurunnya keyakinan masyarakat akan keamanan konsumsi kue skippy "AYU" ini; (2) Kurangnya variasi kue skippy yang diproduksi. Kue skippy yang diproduksi saat ini berbentuk bulat dengan diameter $3 \mathrm{~cm}$. bentuk kue yang seperti ini terkesan kurang variatif dimata konsumen. Konsumen pada umumnya menginginkan bentuk, ukuran maupun taburan topping kue yang lebih variatif; (3) Tidak ada pengelolaan keuangan dan manajemen yang baik. Proses pengelolaan keuangan Kelompok UMKM Kue Skippy "AYU" tidak melakukan pencatatan pendapatan dan pengeluaran secara terperinci dan tidak sesuai standar sehingga seringkali keuntungan yang diperoleh tidak diketahui dengan pasti. Selain itu 
mengakibatkan informasi keuangan sebagai bentuk pertanggungjawaban terhadap anggota kelompok kurang kredibel dan dapat memicu konflik internal kelompok UMKM.

Berdasarkan uraian permasalahan di atas, maka solusi dan target luaran yang diharapkan dalam kegiatan pendampingan ini terdapat dalam Tabel 2 berikut:

Tabel 2. Solusi dan Target Luaran

\begin{tabular}{|c|c|c|}
\hline Permasalahan & Solusi & Target Luaran \\
\hline Tidak ada legalitas produk & $\begin{array}{l}\text { Pendampingan dalam kepengurusan } \\
\text { P-IRT yang diharapkan menunjang } \\
\text { legalitas produk skippy "Ayu" (Pri- } \\
\text { masari, 2018) }\end{array}$ & $\begin{array}{l}\text { 1. Terdaftarnya P-IRT atas UMKM kue Skippy } \\
\text { "Ayu" sehingga meningkatkan keyakinan } \\
\text { masyarakat akan produk kue skippy "Ayu" } \\
\text { mencapai } 90 \% \\
\text { 2. Adanya P-IRT akan meningkatkan kredibilitas } \\
\text { mitra didalam menjalankan usahanya seban- } \\
\text { yak } 100 \% \text {. }\end{array}$ \\
\hline $\begin{array}{l}\text { Kurangnya variasi kue skippy } \\
\text { yang diproduksi }\end{array}$ & $\begin{array}{l}\text { Pemberian pelatihan pembuatan kue } \\
\text { skippy yg lebih variatif seperti mem- } \\
\text { perbesar ukuran kue, menggunakan } \\
\text { berbagai bentuk cetakan kue yg lebih } \\
\text { menarik dan penggunaan berbagai } \\
\text { taburan seperti kacang mete, almond, } \\
\text { kacang tanah, keju dan berbagai } \\
\text { taburan yang sesuai lainnya. }\end{array}$ & $\begin{array}{l}\text { Terjadi peningkatan variasi bentuk kue skippy } \\
\text { sebanyak } 80 \% \text {. Sehingga bentuk dan taburan } \\
\text { kue skippy yang mulanya hanya ada satu jenis } \\
\text { menjadi beragam sehingga memungkinkan } \\
\text { pembeli untuk memilih varian kue sesuai selera } \\
\text { dan kebutuhan. Varian yang lengkap kue skippy } \\
\text { diharapkan dapat memenuhi peningkatan pen- } \\
\text { jualan sebesar } 80 \% \text {. }\end{array}$ \\
\hline $\begin{array}{l}\text { Tidak ada pengelolaan keuan- } \\
\text { gan dan manajemen yang baik }\end{array}$ & $\begin{array}{l}\text { Pendampingan dan Pelatihan Pen- } \\
\text { gelolaan Keuangan dan Manajemen } \\
\text { kepada mitra. Pelatihan keuangan } \\
\text { dilakukan menggunakan bantuan } \\
\text { teknologi untuk mempermudah } \\
\text { proses pelaporan. }\end{array}$ & $\begin{array}{l}\text { Meningkatnya kemampuan mitra UMKM dalam } \\
\text { mengelola keuangannya. Pengelolaan keuan- } \\
\text { gan mitra diharapkan dapat dilakukan dengan } \\
\text { bantuan teknologi informasi. Hal ini untuk } \\
\text { meningkatkan kredibilitas laporan pengelolaan } \\
\text { keuangan kepada anggota UMKM Skippy "Ayu" } \\
\text { yang semula kurang dari 50\% menjadi 80\%. }\end{array}$ \\
\hline
\end{tabular}

\section{METODE}

Pelaksanaan kegiatan Program Kemitraan Masyarakat melalui pendampingan UMKM Kue Skippy secara keseluruhan hingga pelaporan akhir dilakukan selama 7 bulan yakni 5 April-30 Oktober 2021, dengan program pelaksanaan yang dilaksanakan hingga Juni 2021 adalah sebagai berikut:

\section{Pendampingan Pengurusan Izin P-IRT}

Pendampingan Pengurusan izin P-IRT melibatkan mitra dengan memberikan gambaran pentingnya aspek legalitas dalam suatu produk (Kurniawan \& Astuti, 2018). Tahapan yang dilakukan dalam kegiatan ini adalah sebagai berikut: (1) Sosialisasi mengenai pentingnya izin P-IRT dalam produk kue skippy demi kenyamanan konsumen; (2) Sosialisasi tahapan dan prosedur secara teknis dalam pendaftaran izin P-IRT; (3) Mitra melengkapi kelengkapan dokumen yang dibutuhkan dalam proses Perizinan P-IRT; (4) Mitra membuat sampel produk untuk dilakukan uji laboratorium pangan untuk mengetahui kadar zat dan nutrisi yang terkandung dalam kue Skippy "AYU". Hasil uji laboratorium ini selanjutnya diberikan kepada Dinas Kesehatan dalam rekomendasi mengeluarkan izin P-IRT, yang nantinya juga akan dicantumkan dalam kemasan Kue Skippy "AYU".

\section{Konsep Inovasi Produk Kue Skippy "AYU"}

Guna menyasar segmentasi pasar yang lain, inovasi produk dilakukan dengan melibatkan mitra UMKM Skippy "AYU" dengan tim pengusul. Tahapan dalam kegiatan ini meliputi: (1) Brainstorming 
ABDIMAS: Jurnal Pengabdian Masyarakat Universitas Merdeka Malang

Volume 7, No 1, February 2022: 166-177

antara mitra dan pengusul terkait inovasi produk khususnya dalam bentuk dan ukuran dari kue Skippy "AYU"; (2) Pembuatan sampel produk dengan menerapkan inovasi produk yang sudah didiskusikan sebelumnya; (3) Memberikan sampel produk kepada beberapa konsumen dan meminta umpan balik sebagai masukan terkait inovasi produk tersebut; (4) Rilis produk yang sudah mengimplementasikan inovasi produk. Beberapa hal yang dapat dilakukan dalam inovasi produk salah satunya adalah dengan membuat variasi ukuran dimensi dari kue Skippy "AYU" menjadi lebih besar, sehingga dapat menyasar masyarakat yang menggemari ukuran kue dengan dimensi besar, yaitu dari diameter $3 \mathrm{~cm}$ menjadi 5 $\mathrm{cm}$.

\section{Pelatihan dan Pendampingan Pemasaran Online}

Beberapa anggota aktif di UMKM Kue Skippy "AYU" sudah ada yang menguasai teknologi melek teknologi, khususnya teknologi sosial media dan penjualan berbasis online. Sehingga dalam kegiatan ini akan melibatkan beberapa anggota aktif di UMKM Skippy "AYU" dengan materi: (1) Pembuatan konten Instagram dengan foto produk yang estetik dan pengisian caption dan hashtag yang memiliki daya tarik bagi konsumen; (2) Pengisian detail produk Kue Skippy "AYU" yang terdiri dari deskripsi produk, foto produk, jumlah stok yang tersedia beserta pemutakhiran stoknya, alamat dan nomor kontak penjualan yang dapat dihubungi; (3) Pendampingan dalam menangani pemesanan secara online, yang terdiri dari handling online customer, pencatatan pemesanan online, penulisan resi pengiriman barang, pengepakan sehingga tidak membuat kue Skippy "AYU" rusak, hingga penanganan ketika terjadi komplain oleh pelanggan.

\section{Evaluasi}

Sebagai tahap akhir dari kegiatan ini dilakukan evaluasi dengan menilai bagaimana hasil yang dicapai selama kegiatan berlangsung yang dimulai dengan sosialisasi kepada masyarakat (Purwaningsih et al., 2019), pendampingan dalam menginovasi produk, pendampingan pengurusan izin P-IRT, pelatihan pemasaran, serta pelatihan pengelolaan keuangan. Evaluasi menilai bagaimana partisipasi masyarakat yang terlibat dalam kegiatan ini, serta capaian yang dihasilkan dari setiap kegiatan yang diselenggarakan (Setiawan et al., 2020). Hasil dari evaluasi akan dianalisis menjadi bahan rencana tindak lanjut ke depannya baik bagi mitra sebagai arah kebijakan, maupun apa yang dapat dilakukan oleh tim pengusul sebagai upaya keberlanjutan program kegiatan. Proses pemantauan dan tindak lanjut kegiatan ini diharapkan akan terus dilaksanakan oleh tim pelaksana dalam kegiatan PKM selanjutnya sebagai wujud pertanggungjawaban kepada masyarakat.

\section{HASIL DAN PEMBAHASAN}

Hasil dari kegiatan pendampingan bagi mitra UMKM Kue Skippy adalah terjadinya peningkatan pemberdayaan dan pendapatan mitra melalui tahapan pendampingan yang dilakukan, meliputi: 1) Pendampingan Pengurusan izin P-IRT, 2) Inovasi Produk Kue Skippy "AYU", 3) Pelatihan dan Pendampingan Pemasaran Online, 4) Evaluasi. Secara detail berikut hasil dari kegiatan pendampingan tersebut:

\section{Pendampingan Pengurusan Izin P-IRT}

Sosialisasi pengurusan P-IRT dilaksanakan pada tanggal 20 April 2021 dengan melibatkan pihak ketua mitra UMKM Kue Skippy "AYU", pegawai pabrik UMKM Kue Skippy "AYU", dan beberapa perwakilan dari masyarakat. Di dalam sosialisasi ini dijelaskan beberapa hal bahwa dengan adanya P-IRT, artinya produk Kue Skippy "AYU" ini sudah siap dan layak edar. Tidak ada larangan yang menyatakan produk tersebut tidak sah untuk diedarkan di pasaran, karena sudah terdaftar di Dinas Kesehatan. Dalam proses 
pendaftaran, produk pangan industri rumah tangga akan diuji dan diseleksi secara ketat oleh pihak dari dinas kesehatan. Selain produk, pemilik usaha juga dilakukan tes pengetahuan terhadap bahan pangan serta diberikan edukasi melalui bimbingan. Setelah lolos tahap ini, baru kemudian izin P-IRT bisa dikeluarkan. Mengingat prosedur yang dilalui cukup ketat, sehingga bisa dipastikan bahwa keamanan dan mutu produk yang beredar sudah terjamin.

Selain itu, juga diberikan pemahaman bahwa manfaat lainnya dengan adanya izin P-IRT adalah pada Saat ini para konsumen sudah cerdas dan selektif dalam pemilik produk. Mereka sudah bisa membedakan mana produk yang aman dan yang tidak dengan melihat informasi kemasan. Ketika tercantum izin P-IRT pada kemasan produk kue Skippy "AYU" yang sudah beredar dipasaran, para konsumen akan lebih percaya. Mereka tidak akan ragu lagi untuk membeli produk tersebut kemudian mengkonsumsinya.

Selanjutnya adalah pendaftaran untuk pelatihan keamanan pangan dari Dinas Kesehatan. Di dalam pelatihan ini, mitra UMKM Kue Skippy "AYU" diberikan pembekalan sehingga mampu memproduksi makanan yang higienis, aman, memiliki mutu yang baik, serta tidak menyalahi atau bertentangan dengan norma agama, keyakinan dan budaya masyarakat. Peserta kegiatan diberikan pre-test dan post-test selama dan setelah pelatihan, dimana hasil dari tes tersebut dijadikan dasar dalam penerbitan sertifikat pelatihan keamanan pangan yang menjadi persyaratan dalam pendaftaran izin P-IRT ke Dinas Penanaman Modal Pelayanan Terpadu Satu Pintu (DPMPTSP) Kota Palembang.

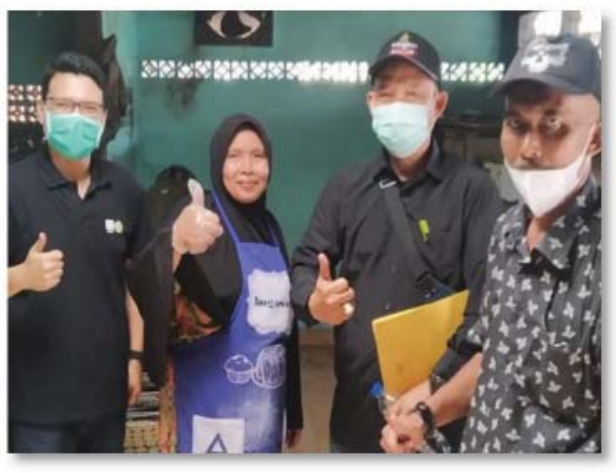

Gambar 3. Bersama Pemateri Penyuluhan Keamanan Pangan

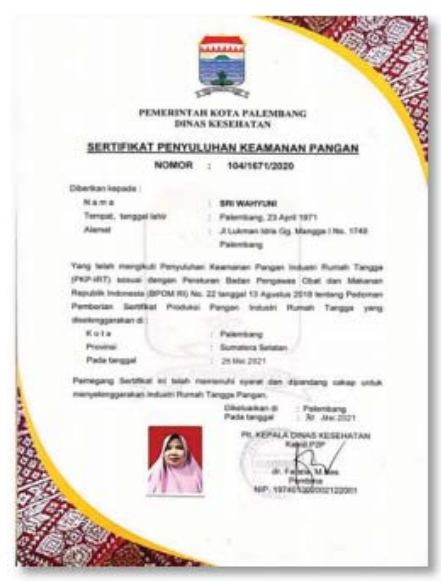

Gambar 4. Sertifikat Pelatihan Keamanan Pangan 
ABDIMAS: Jurnal Pengabdian Masyarakat Universitas Merdeka Malang Volume 7, No 1, February 2022: 166-177

Setelah mitra mendapatkan pelatihan dan lulus dari tes dasar keamanan pangan, selanjutnya sertifikat pelatihan keamanan pangan diterbitkan oleh Dinas Kesehatan per tanggal 30 Mei 2021 sebagai dasar persyaratan dalam pendaftaran izin P-IRT. Gambar 4 menunjukkan sertifikat pelatihan keamanan pangan bagi UMKM

Pendaftaran P-IRT dilakukan di Dinas Penanaman Modal Pelayanan Terpadu Satu Pintu (DPMPTSP) yang berlokasi di Jl. Gub H Bastari, 15 Ulu, Jakabaring, Kota Palembang. Dalam proses pendaftaran melampirkan beberapa dokumen dan formulir yang telah diisi oleh mitra UMKM Kue Skippy "AYU", yang terdiri dari: a) Fotokopi KTP, b) Pasfoto 3 x 4, c) Fotokopi Sertifikat Penyuluhan Keamanan Pangan, d) Surat Keterangan Domisili yang dikeluarkan oleh Kelurahan setempat, e) Surat Pernyataan Kebersihan, dan f) Formulir Pendaftaran yang sudah diisi. Gambar 5 menunjukkan proses pendaftaran Izin P-IRT di DPMPTSP Kota Palembang dan Gambar 6 merupakan bukti pendaftaran yang dikeluarkan oleh DPMPTSP Kota Palembang. Sebelum proses penerbitan sertifikat Izin P-IRT, dari pihak DPMPTSP akan melakukan verifikasi data dan survey ke lokasi pabrik mitra untuk melihat kondisi kebersihan, keamanan pangan, pengelolaan stok bahan baku dan aspek teknis lainnya yang terkait dengan produksi pangan.
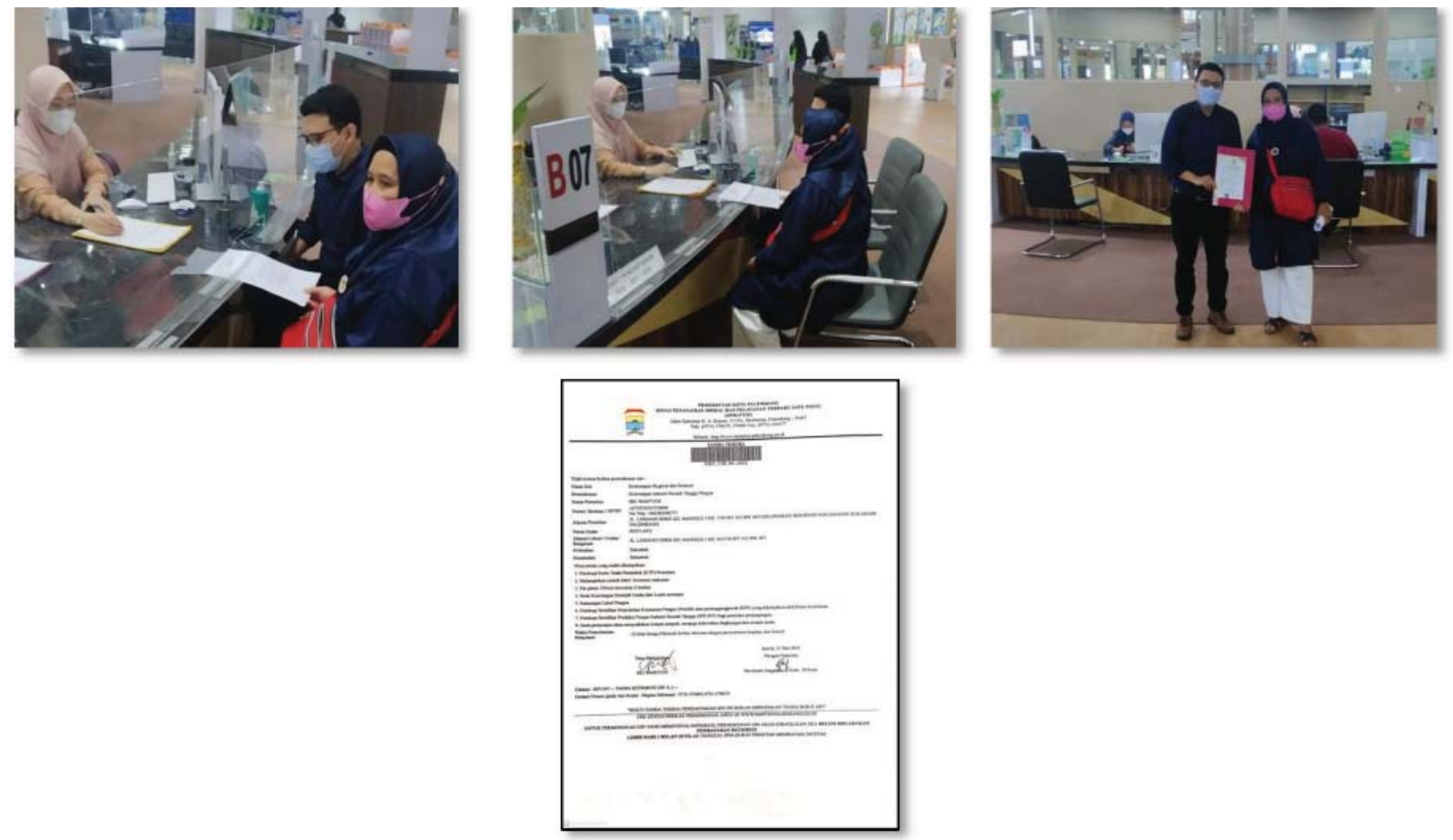

Gambar 5. Pendaftaran Izin P-IRT bersama Mitra UMKM Kue Skippy "AYU" di DPMPTSP Kota Palembang

Gambar 6. Bukti Pendaftaran

Setelah dilakukan survey dari DPMPTSP Kota Palembang, tahapan akhir adalah penerbitan sertifikat izin P-IRT. Proses penerbitan dari DPMPTSP dilakukan maksimal 10 hari kerja setelah dilakukan survey lokasi. Sertifikat Izin P-IRT memuat informasi mengenai Nomor P-IRT, tanggal penerbitan P-IRT, masa berlaku P-IRT selama 3 tahun sejak penerbitan, dan informasi dasar dari mitra UMKM Kue Skippy "AYU" yang terdiri dari; Nama IRT, Alamat, Nama Pemilik, Jenis Pangan, Kemasan Primer, Merk Dagang. Gambar 7 menunjukkan sertifikat Izin P-IRT mitra UMKM Kue Skippy "AYU". 


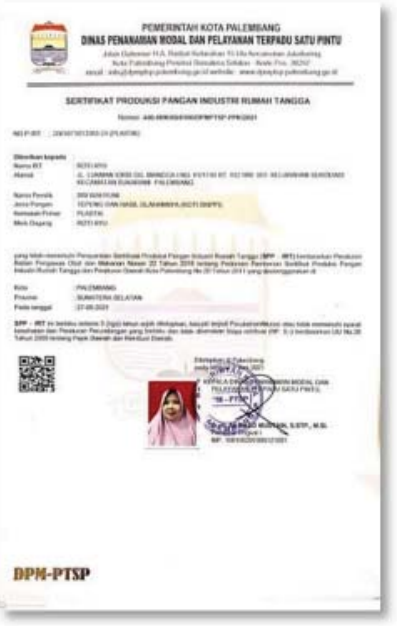

Gambar 7. Sertifikat Perizinan P-IRT

\section{Inovasi Produk Kue Skippy "AYU"}

Sebelum mengeksekusi inovasi yang akan diterapkan pada mitra UMKM Kue Skippy "AYU", terlebih dahulu dilakukan diskusi mendalam bersama mitra dimana membahas beberapa hal teknis yang berkenaan dengan: (1) variasi produk kue skippy yang terdiri dari beberapa taburan seperti kacang almond, keju dan coklat; (2) Diameter kue Skippy; (3) Konsep Branding yang akan diimplementasikan di sosial media Instagram maupun marketplace sebagai platform yang digunakan dalam pemasaran produk. Dari hasil diskusi ini, mitra menyatakan kesediaannya untuk dilakukan inovasi produk yang berfokus pada aspek hasil produk pangan kue Skippy, branding produk, dan inovasi pemasaran melalui platform media sosial dan marketplace.
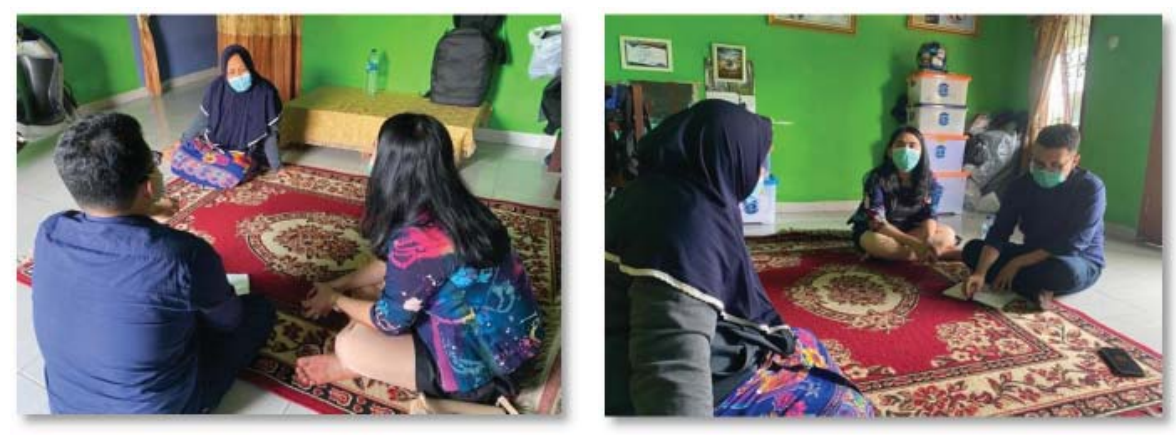

Gambar 8. Diskusi bersama mitra UMKM Kue Skippy "AYU"

Setelah ditetapkan konsep yang akan diimplementasikan dalam inovasi produk yang terdiri dari penambahan varian taburan coklat, kacang almond dan keju serta variasi ukuran kue skippy, maka dilakukan uji coba pembuatan sampel produk kue skippy. Adapun tahapan dalam pembuatan kue skippy adalah sebagai berikut: (1) Penggilingan kacang: Dalam proses ini diperlukan 10-12 kg kacang yang sudah dijemur/dikeringkan selama +/- 6 Jam; (2) Pencampuran Adonan: Proses ini dilakukan dengan mencampur garam, minyak sayur dan mentega, gula yang sudah dihaluskan; (3) Pengadonan Tepung Terigu: Pada tahapan ini menggunakan terigu $25 \mathrm{~kg}$ dalam 10-12 kg. Terigu disangrai terlebih dahulu, kemudian dituang ke dalam adonan kacang tanah yang sudah digiling sebelumnya. Dalam pengadonan 
ABDIMAS: Jurnal Pengabdian Masyarakat Universitas Merdeka Malang Volume 7, No 1, February 2022: 166-177

kue, diperlukan tenaga minimal 4 tenaga pengolah adonan kue skippy; (4) Proses Pembakaran Kue: Loyang yang berisi adonan Kue Skippy "AYU" selanjutnya dimasukan ke dalam oven pembakaran. Kapasitas produksi Oven mampu menampung 20 loyang panggang. Dalam proses pembakaran loyang dilakukan dengan membalikan loyang atas ke bawah, begitu pun sebaliknya sehingga menghasilkan pemanasan yang merata; (5) Pembungkusan: Kue yang sudah dipanaskan selanjutnya ditiriskan untuk dibungkus dalam pembungkus plastik bening. Dalam 1 bungkus berisi 20 kue Skippy yang sudah dipisah dalam plastik kecil. Untuk harga jual pabrik seharga Rp 8.000 / bungkus dan harga pasar bervariasi mulai dari Rp 10.000 hingga Rp 15.000 / bungkus.
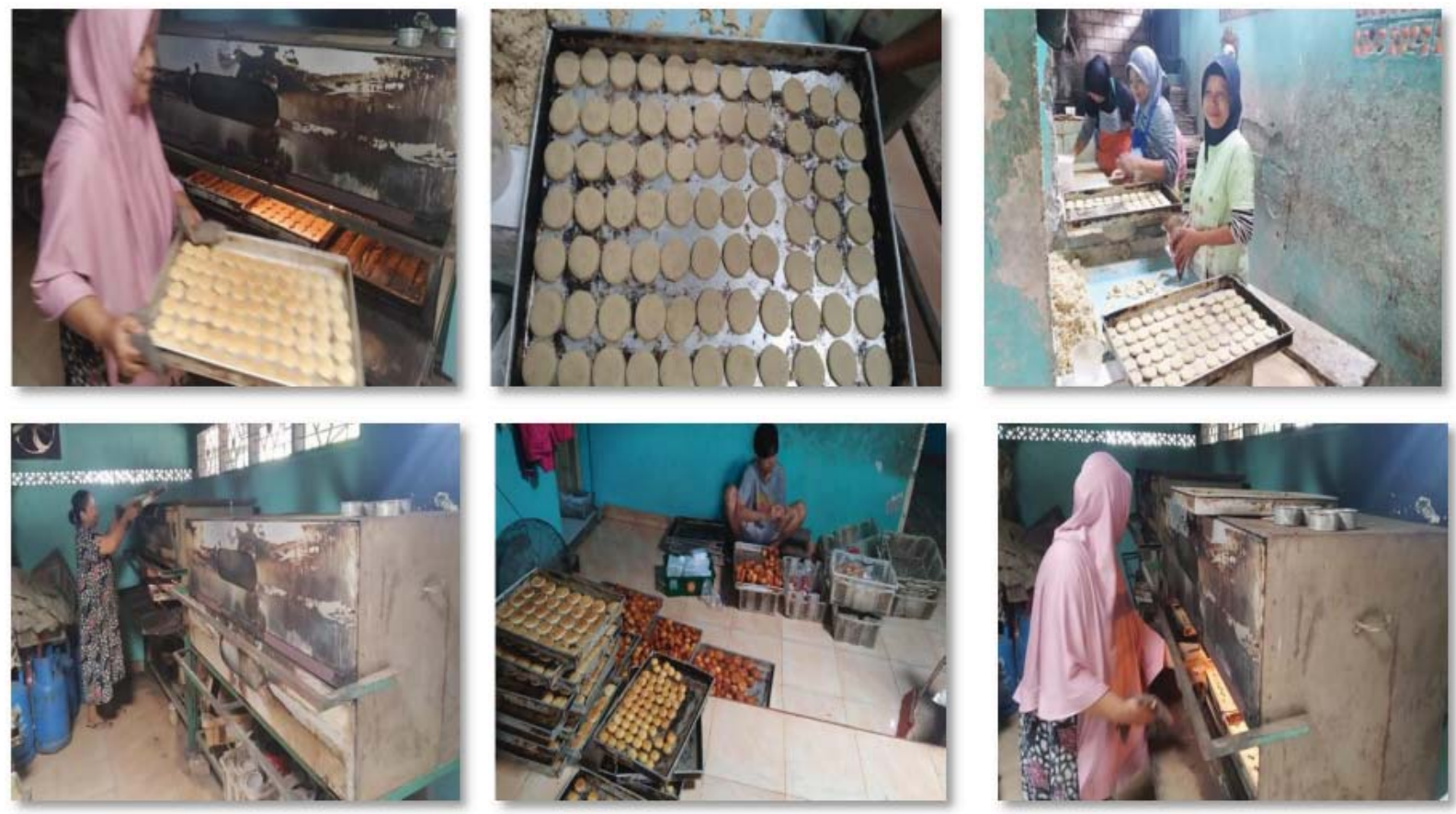

Gambar 9. Proses Produksi Sampel Produk Kue Skippy "AYU"

\section{Pelatihan dan Pendampingan Pemasaran Online}

Instagram menjadi salah satu platform dalam pemasaran online produk UMKM Kue Skippy "AYU". Dalam tahapan ini dilakukan beberapa kegiatan, yakni: (1) Membuat Akun Instagram Kue Skippy "AYU" dengan akun @skippi_palembang, yang dilengkapi dengan nomor kontak/WhatsApp yang bisa dihubungi, alamat, URL YouTube; (2) Membuat foto estetik dengan konsep "kekinian" melalui aplikasi foto Android, yang nantinya akan di-post ke dalam akun Instagram tersebut; (3) Mencantumkan Caption Deskripsi, Detail Produk, hashtag yang memudahkan dalam pencarian.

Dalam pelatihan pemasaran dilakukan selama 2 hari yang terdiri dari materi pendampingan pemasaran melalui sosial media dan pendampingan pengelolaan manajemen pabrik dan keuangan dari tanggal 16-17 Mei 2021. Peserta kegiatan terdiri dari pemilik UMKM Kue Skippy "AYU", pegawai pabrik, beberapa perwakilan masyarakat setempat. Berikut agenda kegiatan dari pendampingan dan pelatihan mitra: 
Assistance in optimizing production and sales for MSME Skippy Cookie "AYU" in Sukodadi Village, Palembang Indra Griha Tofik Isa, Riana Mayasari

Tabel 3. Agenda kegiatan pelatihan dan pendampingan Mitra UMKM Kue Skippy "AYU"

\begin{tabular}{|c|c|}
\hline $\begin{array}{c}\text { Pelatihan Hari } \\
\text { ke-1 }\end{array}$ & Pendampingan Pemasaran melalui Sosial Media \\
\hline Aktifitas & $\begin{array}{l}\text { - Memasukan konten foto ke dalam Instagram } \\
\text { - Membuat caption yang bersifat marketable dan merepresentasikan dari produk Kue Skippy "AYU } \\
\text { - Meningkatkan engagement dengan optimalisasi like dan share }\end{array}$ \\
\hline Tujuan & $\begin{array}{l}\text { - UMKM Kue Skippy "AYU" dapat menggunakan sosial media Instagram sebagai kanal dalam pemasa- } \\
\text { ran } \\
\text { - Mengoptimalkan media sosial Instagram dalam pemasaran produk } \\
\text { - Meningkatkan penjualan produk kue Skippy "AYU" }\end{array}$ \\
\hline $\begin{array}{c}\text { Pelatihan Hari } \\
\text { ke-2 }\end{array}$ & Pendampingan Pengelolaan Manajemen Pabrik dan Keuangan \\
\hline Aktifitas & $\begin{array}{l}\text { - Pelatihan pencatatan bahan baku, bahan keluar dan bahan yang digunakan dalam produk dengan } \\
\text { menggunakan metode First in First Out } \\
\text { - Pelatihan manajemen keuangan dengan pencatatan keuangan sederhana. } \\
\text { - Pelatihan pencatatan keuangan dengan menggunakan aplikasi microsoft excel }\end{array}$ \\
\hline Tujuan & $\begin{array}{l}\text { - Terjadi peningkatan kapasitas dalam pengelolaan manajemen bahan baku } \\
\text { - UMKM Kue Skippy "AYU" dapat mengetahui estimasi keuntungan yang dihasilkan dalam suatu siklus } \\
\text { tertentu } \\
\text { - Terjadi peningkatan transparansi laporan keuangan, objektifitas dalam data produksi kue yang di- } \\
\text { hasilkan serta menghindari dari penyalahgunaan administrasi yang dilakukan oleh pegawai UMKM } \\
\text { Kue Skippy "AYU" }\end{array}$ \\
\hline
\end{tabular}

Gambar 10 menunjukkan proses pelaksanaan kegiatan pelatihan pemasaran melalui sosial media dan pendampingan pengelolaan manajemen pabrik dan keuangan
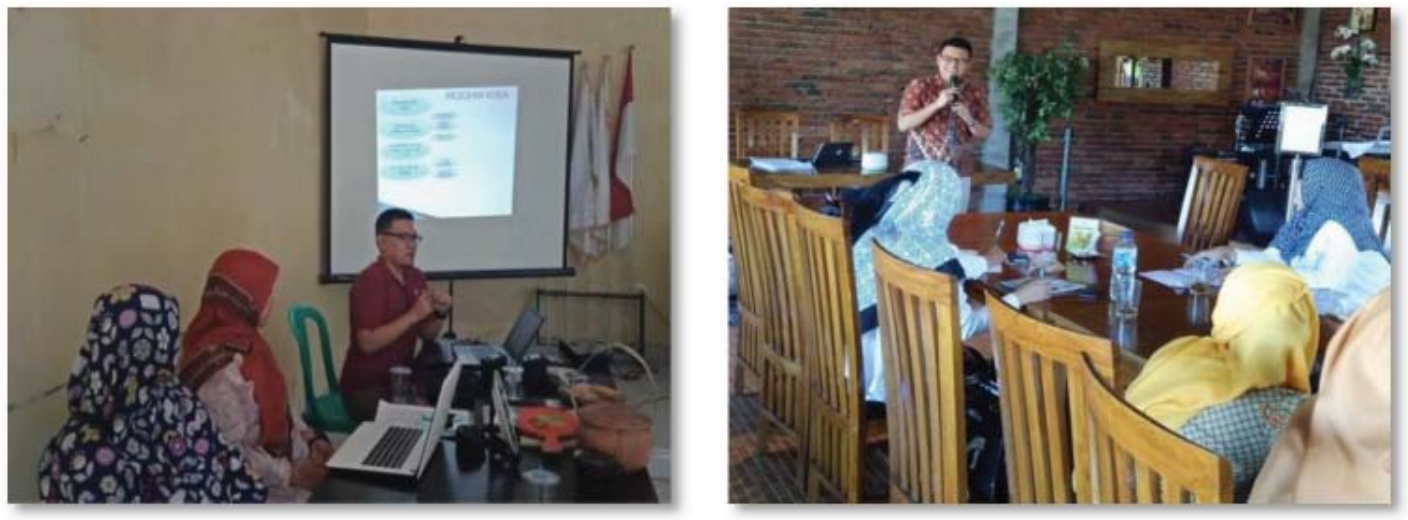

Gambar 10. Pelatihan Pemasaran dengan Instagram pada hari ke-1 (Kiri) dan Pelatihan Pengelolaan Keuangan pada hari ke-2 (Kanan)

\section{Evaluasi}

Sebagai usaha peningkatan dan potensi keberlanjutan dari pelaksanaan program yang diterapkan kepada mitra UMKM Kue Skippy "AYU" maka dilakukan evaluasi dengan melihat kondisi sebelum dan setelah diterapkan Program Kemitraan Masyarakan UMKM Kue Skippy "AYU", sebagaimana dalam tabel 4. 
ABDIMAS: Jurnal Pengabdian Masyarakat Universitas Merdeka Malang

Volume 7, No 1, February 2022: 166-177

Tabel 4. Kondisi Mitra sebelum dan setelah pelaksanaan program kemitraan masyarakat

\begin{tabular}{|c|c|c|c|}
\hline Deskripsi & Kondisi Sebelum & Kondisi Setelah & Keterangan \\
\hline Legalitas Perusahaan & Tidak ada & Ada & Sertifikat perizinan $\mathrm{P}$-IRT \\
\hline $\begin{array}{l}\text { Variasi Produk Kue } \\
\text { Skippy "AYU" }\end{array}$ & Tidak ada taburan & $\begin{array}{l}\text { Terdapat } 3 \text { taburan : coklat, ka- } \\
\text { cang almond dan keju }\end{array}$ & - \\
\hline $\begin{array}{l}\text { Peningkatan pendapa- } \\
\text { tan dan produktifitas }\end{array}$ & $\begin{array}{l}\text { Penjualan pendapatan dan } \\
\text { produktifitas } 65 \%\end{array}$ & $\begin{array}{l}\text { Peningkatan pendapatan dan } \\
\text { produktifitas } 80 \%\end{array}$ & $\begin{array}{l}\text { Faktor Pendukung: Pro- } \\
\text { mosi media sosial }\end{array}$ \\
\hline Pemasaran Produk & Pembeli mendatangi langsung & $\begin{array}{l}\text { Pembeli mendatangi langsung } \\
\text { dan melalui sosial media }\end{array}$ & Sosial media: Instagram \\
\hline $\begin{array}{l}\text { Pencatatan Laporan } \\
\text { Keuangan }\end{array}$ & $\begin{array}{l}\text { Hanya dengan perhitungan } \\
\text { perkiraan, mitra tidak mengeta- } \\
\text { hui kondisi keuangan yang riil }\end{array}$ & $\begin{array}{l}\text { Penerapan pencatatan laporan } \\
\text { keuangan untuk mengetahui } \\
\text { kondisi keuangan apakah dalam } \\
\text { kondisi rugi / untung }\end{array}$ & - \\
\hline $\begin{array}{l}\text { Manajemen Bahan Baku } \\
\text { dan Produksi }\end{array}$ & $\begin{array}{l}\text { Belum menerapkan manajemen } \\
\text { bahan baku. Dampak: terjadi } \\
\text { kerugian yang tidak tercatat }\end{array}$ & $\begin{array}{l}\text { Mitra dapat mengklasifikasikan } \\
\text { bahan baku yang direpresentasi- } \\
\text { kan dengan Kode Produksi }\end{array}$ & - \\
\hline
\end{tabular}

\section{SIMPULAN DAN SARAN}

Program Kemitraan Masyarakat berupa pendampingan optimalisasi penjualan dan produksi pada UMKM Kue Skippy "AYU" yang berlokasi di Kelurahan Sukodadi - Kota Palembang menghasilkan peningkatan pendapatan dan produktifitas yang semula di angka $65 \%$ menjadi $80 \%$. Tahapan kegiatan yang dilakukan terdiri dari: (1) Pendampingan Pengurusan Izin P-IRT; (2) Inovasi produk Kue Skippy "AYU"; (3) Pelatihan dan pendampingan pemasaran online; (4) Evaluasi. Beberapa kondisi setelah diterapkan Program Kemitraan Masyarakat ini adalah adanya legalitas perusahaan berupa perizinan P-IRT; produk inovasi berupa varian taburan skippy yang terdiri dari coklat, kacang almond dan keju; pemasaran dilakukan secara online; serta terjadinya peningkatan kapasitas mitra dengan manajemen keuangan dan bahan baku produksi.

Upaya keberlanjutan perlu terus dilakukan terutama dalam komitmen updating konten pemasaran melalui sosial media Instagram sehingga pengembangan UMKM Kue Skippy "AYU" tidak hanya sebatas dalam Program Kemitraan Masyarakat, namun secara mandiri dapat mengembangkan kapasitasnya baik dari segi produksi maupun penjualan. Sehingga secara tidak langsung akan menjadi penggerak perekonomian masyarakat sekitar lokasi UMKM Kue Skippy "AYU".

\section{UCAPAN TERIMA KASIH}

Ucapan terima kasih disampaikan kepada Direktorat Riset dan Pengabdian Masyarakat Kementerian Pendidikan, Kebudayaan, Riset dan Teknologi atas pendanaan pengabdian masyarakat untuk skim Program Kemitraan Masyarakat; kepada Pusat Penelitian dan Pengabdian Masyarakat (P3M) Politeknik Negeri Sriwijaya yang telah mengakomodasi selama proses kegiatan, serta mitra UMKM Kue Skippy "AYU" dan masyarakat sekitar Kelurahan Sukodadi, Palembang Indonesia.

\section{DAFTAR PUSTAKA}

Badan Pusat Statistik Kota Palembang. (2019). Statistik Daerah Statistik Daerah Kota Palembang. BPS Kota Palembang.

Badan Pusat Statistik Kota Palembang. (2020). Kecamatan Sukarami Dalam Angka 2020. BPS Kota Palembang. 
Harsawardana, H., Ulfah, M., Samodra, B., \& Suharyono, A. B. (2020). PPUPIK unit produksi mesin otomatis bagi UMKM pangan untuk meningkatkan standar mutu produk pangan. Abdimas: Jurnal Pengabdian Masyarakat Universitas Merdeka Malang, 5(3), 266-278. https://doi.org/10.26905/abdimas.v5i3.4662

Isa, I. G. T., Setiawan, I. R., \& Jhoansyah, D. (2019). Potensi industri "keripik enye" dalam peningkatan kesejahteraan masyarakat Desa Waluran Kabupaten Sukabumi. Jurnal Masyarakat Madani, 3(1), 29-40. https://doi.org/10.31764/jmm.v3i1.920

Kurniawan, D. A., \& Astuti, R. Y. (2018). Pendampingan pengurusan izin PIRT sebagai langkah awal pengembangan dan perluasan pasar bagi produk lokal IKM Ponorogo. Khadimul Ummah: Journal of Social Dedication, 1(2), 93-101. http://doi.org/10.21111/ku.v1i2.2490

MC Kota Palembang. (2019). Masuk 10 Besar Kota Kreatif, Palembang Raih Penghargaan Bekraf. Portal Berita Info Publik.

Nursalim, N., Sampeallo, A. S., Wahid, A., \& Meok, N. J. (2021). Pendampingan dan Penerapan teknologi tepat guna untuk peningkatan produktivitas usaha mebel Kota Kupang. Abdimas: Jurnal Pengabdian Masyarakat Universitas Merdeka Malang, 6(1), 82-89.

https://doi.org/10.26905/abdimas.v1i1.4943

Primasari, I. A. (2018). Pemberdayaan masyarakat Dusun Gumawang melalui pendampingan ijin P-IRT. Jurnal Pemberdayaan: Publikasi Hasil Pengabdian Kepada Masyarakat, 1(2), 125. https://doi. org/10.12928/jp.v1i2.316

Purwaningsih, E., Muslikh, \& Suhaeri. (2019). Peningkatan kualitas produk UMKM Kampung Wisata Bisnis Tegal Waru dalam upaya komersialisasi produk berdaya saing dan berbasis informasi teknologi. Jurnal Abdimas Unmer Malang, 4(1), 51-57. https://doi.org/10.26905/abdimas.v4i1.3239

Setiawan, I. R., Isa, I. G. T., Hestiana, S., \& Tsani, A. (2020). Kampung Eduwisata Hanjeli di Desa Waluran Mandiri Kabupaten Sukabumi. Abdimas: Jurnal Pengabdian Masyarakat Universitas Merdeka Malang, 5(3), 300-311. https://doi.org/10.26905/abdimas.v5i3.4382

Suparjo, \& Hariastuti, N. L. P. (2017). Pendampingan pengabdian kepada masyarakat untuk UKM produk tempe di Kapasjaya. Jurnal Pengabdian LPPM Untag Surabaya, 2(3), 1-9.

https://doi.org/10.30996/jpm17.v2i03.1069.g951 